\title{
A new Early Devonian palaeozygopleurid gastropod from the Prague Basin (Bohemia) with notes on the phylogeny of the Loxonematoidea
}

\author{
JIŘí FRÝDA, LENKA FERROVÁ, STANISLAVA BERKYOVÁ \& BARBORA FRÝDOVÁ
}

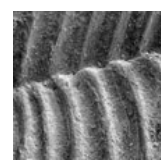

\begin{abstract}
A new palaeozygopleurid gastropod, Palaeozygopleura vaneki sp. nov., is described from the Emsian Chýnice Limestone (Novakia elegans Zone, upper part of the Zlíchov Formation; late Early Devonian) of the Prague Basin (Bohemia). The phylogeny of the superfamily Loxonematoidea and the origin of planktotrophy are briefly discussed. It is suggested that the large protoconchs of the Palaeozygopleuridae and Loxonematidae might represent a grade before the inception of planktotrophy. Key words: Mollusca, Loxonematoidea, Palaeozygopleuridae, Gastropoda, planktotrophy, Emsian, Bohemia.
\end{abstract}

FrÝdA, J., FerrovÁ, L., BerkyovÁ, S. \& FrÝdovÁ, B. 2008. A new Early Devonian palaeozygopleurid gastropod from the Prague Basin (Bohemia) with notes on the phylogeny of the Loxonematoidea. Bulletin of Geosciences 83(1), 93-100 (1 figure). Czech Geological Survey, Prague. ISSN 1214-1119. Manuscript received December 28, 2007; accepted in revised form January 15, 2008, issued March 31, 2008.

Jiři Frýda, Czech Geological Survey, P.O.B. 85, 11821 Prague 1, and Faculty of Environmental Sciences, CULS, 165 21 Prague 6, Czech Republic, fryda@cgu.cz • Lenka Ferrová and Stanislava Berkyová, Czech Geological Survey, P.O.B. 85, Praha 011, 118 21, Czech Republic; lenka.ferrova@geology.cz, berkyova@cgu.cz・Barbora Frýdová, VÚRV v.v.i., Research Institute, Drnovská 507, 16106 Prague - Ruzyně, Czech Republic; frydova@vurv.cz.

Palaeozygopleurid gastropods represent a distinctive group of Middle Paleozoic gastropods (Fig. 1) occurring in Devonian strata of Europe, North America, Australia, and central Asia (Horný 1955; Linsley 1968; Rollins et al. 1971; Kesling \& Chilman 1975; Tassell 1982; Blodgett 1992; Blodgett \& Johnson 1992; Frýda 1993, 1999b, 2000; Frýda \& Blodgett 2004; Cook 1995, 1997; Cook \& Camilleri 1997; Cook et al. 2003; Cook \& Nützel 2005; Gubanov et al. 1995; Blodgett et al. 1999; Heidelberger \& Bandel 1999; Heidelberger 2001, 2007; Amler \& Heidelberger 2003; Heidelberger \& Koch 2005; Krawczyński 2002, 2006). Early Devonian palaeozygopleurids are considered to be a typical element of the Old World Realm (Blodgett et al. 1988, 1990). Later, in the Middle and Late Devonian, palaeozygopleurid gastropods also occurred in another biogeographic realm (the Eastern American Realm). Generally palaeozygopleurid gastropods were restricted to warm to tropical environments. Despite the fact that palaeozygopleurid gastropods are easily recognized by their shell characters, their phylogeny is still poorly known. In this short paper we describe a new Early Devonian palaeozygopleurid gastropod from Bohemia and briefly discuss the phylogeny of the Loxonematoidea and the origin of planktotrophy.

\section{Bohemian palaeozygopleurids}

Palaeozygopleurid gastropods were initially recognized as a separate group of the Paleozoic gastropods by Horný (1955) in Devonian strata of Bohemia. Gastropod faunas of the Prague Basin (Bohemia) hitherto contained 19 species and subspecies, which belong to Palaeozygopleura (Palaeozygopleura) Horný, 1955, Palaeozygopleura (Palaeozyga) Horný, 1955, Palaeozygopleura (Bojozyga) Horný, 1955, Palaeozygopleura (Bohemozyga) Frýda \& Bandel, 1997, Devonozyga Horný, 1955, and Pragozyga Frýda, 1999b (Fig. 1). The vast majority of Bohemian species were described by Horný in 1955 and they were derived mainly from several older fossil collections. During the last 50 years intensive field studies better specified the stratigraphic position of many of these localities. The oldest hitherto known Bohemian palaeozygopleurid gastropod, Palaeozygopleura chlupaci Frýda, 1993, comes from the early Lochkovian Monograptus uniformis Biozone (Early Devonian; Frýda \& Manda 1997; Carls et al. 2007). This species was considered to be the oldest member of the family, but recently the first Silurian palaeozygopleurid gastropod belonging to the genus Medfrazyga Frýda \& Blodgett, 2004 (Fig. 1I) was discovered from Ludlow strata of the Silurian Heceta Formation of Prince of Wales Island, Alaska (Rohr et al. 2008). 
Palaeozygopleura chlupaci is the only palaeozygopleurid gastropod in the Lochkov Formation of the Prague Basin. Diversity of palaeozygopleurid gastropods increased during the Pragian and early Emsian (Praha Formation). Six species and subspecies belonging to Palaeozygopleura (Palaeozygopleura), Palaeozygopleura (Palaeozyga), Palaeozygopleura (Bojozyga), and Pragozyga are known from the Praha Formation (Horný 1955, Frýda 1999b; Fig. 1A, B, L, M). The diversity of palaeozygopleurid gastropods was also high during the Emsian and the earliest Eifelian (Daleje-Třebotov Formation; see also Turek 2007). The highest diversity was recorded in the uppermost part of Daleje-Třebotov Formation, where 10 species and subspecies belonging to Palaeozygopleura ( $\mathrm{Pa}$ laeozygopleura), Palaeozygopleura (Palaeozyga), Palaeozygopleura (Bojozyga), Palaeozygopleura (Bohemozyga), and Devonozyga are known (Horný 1955, Frýda \& Bandel 1997; Fig. 1C, E, J, K). On-going study of the Basal Choteč event (SB, unpublished data; see also Zusková 1991) reveals that the majority of these taxa are from the Polygnatus costatus partitus Biozone, and thus they are of earliest Eifelian age. Chlupáč (1959, p. 478) mentioned an occurrence of a new species of Palaeozygopleura from the Eifelian Acanthopyge Limestone on southern slope of the Zadní Kobyla Hill (Koněprusy area). However, this species was never described or figured and the material no longer exists. In contrast to a high diversity of palaeozygopleurids in the earliest Eifelian strata below the Basal Choteč event, there is no reliable record for any occurrence of palaeozygopleurid gastropod above this event in the overlying Eifelian Choteč Formation. The latter event thus crucially influenced the evolution of Bohemian palaeozygopleurid gastropods, which were considered to be typical elements of the Early Devonian Plectonotus (Boucotonotus)-Palaeozygopleura Community Group for almost 20 my.

\section{Systematic paleontology}

Class Gastropoda Cuvier, 1797

Superfamily Loxonematoidea Koken, 1889

Family Palaeozygopleuridae Horný, 1955

Remarks. - Knight et al. (1960) included four families, Loxonematidae Koken, 1889, Palaeozygopleuridae Horný,
1955, Pseudozygopleuridae Knight, 1930, and Zygopleuridae Wenz, 1938, in the superfamily Loxonematoidea. Teleoconch and protoconch data suggest that the Loxonematidae are a sister taxon of the Palaeozygopleuridae. Phylogenetic relationships of the latter families to the Pseudozygopleuridae and Zygopleuridae are uncertain (see discussion below and classification of Bouchet et al. 2005).

\section{Genus Palaeozygopleura Horný, 1955}

Type species. - Zygopleura alinae Perner, 1907; Pragian, Early Devonian; Dvorce-Prokop Limestone, Praha Formation; Dvorce, Prague, Prague Basin, Bohemia.

\section{Palaeozygopleura vaneki sp. nov.}

Figure $1 \mathrm{~F}-\mathrm{H}$

Holotype. - Specimen figured here on Fig. 1F-H, ČGU JF 851, Jiří Frýda collection, Czech Geological Survey (Prague).

Name. - The species is named in honor of the late Jiři Vaněk (Prague), who made great contributions to our present understanding of Early and Middle Paleozoic trilobite faunas. Jiří Vaněk also discovered the type material of and recognized this new species and passed it together with much important data on paleontology in the Prague Basin to the senior author of this contribution.

Type locality. - Čeřinka hillside, south of Bubovice, Prague Basin; locality description with a list of hitherto known fossils can be found in Chlupáč (1984) and Havlíček \& Vaněk (1996).

Type horizon. - The Chýnice Limestone (Novakia elegans Zone, upper part of the Zlíchov Formation; middle Emsian, late Early Devonian).

Other material. - About two hundred shells. Forty shells selected as paratypes: ČGU JF 852-891, Jiří Frýda collection, Czech Geological Survey (Prague).

Figure 1. Devonian palaeozygopleurid gastropods. • A - Pragozyga costata Frýda, 1999, × 21. • B - Palaeozygopleura (Palaeozygopleura) alinae (Perner, 1907), × 19. • C - Palaeozygopleura (Palaeozyga) bohemica Horný, 1955, × 18. • D - Palaeozygopleura (Rhenozyga) reifenstuhli Frýda \& Blodgett, 2004, $\times 26$. • E - Palaeozygopleura (Bohemozyga) kettneri (Horný, 1955), × 20.・F-Palaeozygopleura vaneki sp. nov., $\times 13$. • G - detailed view of suture in Palaeozygopleura vaneki sp. nov., $\times 115 . \cdot \mathrm{H}-$ detailed view showing shell ornamentation in Palaeozygopleura vaneki sp. nov., $\times 50$. - I - Medfrazyga clauticae Frýda \& Blodgett, 2004, × 21. • J, K - detailed view showing large protoconch of Palaeozygopleura (Bohemozyga) kettneri, $\times 29$ and $\times 40$. $\bullet$ L - detailed view of shell base in Palaeozygopleura (Palaeozygopleura) alinae, $\times 21$. $\bullet$ M - detailed view showing large protoconch of Pragozyga costata, $\times 48$. A, B, L, M-Malá Chuchle near Prague (A, M), Prague-Barrandov (B, L), Dvorce-Prokop Limestone (Pragian to early Emsian, Praha Formation, Bohemia). • C, E, J, K - Holyně near Prague, Třebotov Limestone (late Emsian to earliest Eifelian, Daleje-Třebotov Formation, Bohemia). - D, I - unnamed Emsian strata on the south flank of Limestone Mountain (Medfra B-4 quadrangle, west-central Alaska Limestone). - F-H - Čeřinka Hill near Bubovice, Chýnice Limestone (middle Emsian, Zlíchov Formation, Bohemia). 

Diagnosis. - Species with markedly convex whorl profile; whorls ornamented by rounded fine costae with triangular profile; about 50 to 60 asymmetrical curved costae per volution on adult whorls; costae contain an angle about 60 degrees with the lower suture and meet the upper suture in an opisthocline direction.

Description. - Palaeozygopleura vaneki has a small high-spired, dextrally coiled shell with slightly convex sides; the pleural angle is about 18 degrees. The whorls are slightly adpressed on preceding whorls (Fig. 1F); the whorl profile is markedly convex and the sutures relatively deep. The shell base is smooth and anomphalous; the whorls are ornamented by fine rounded costae with a triangular profile (Fig. 1G, H); the width of the costae is smaller than their distance of separation; there are about 50 to 60 asymmetrical curved costae per volution on adult whorls; the costae run almost straight in a prosocline direction to the middle of whorl and contain an angle of about 60 degrees with the lower suture; costae above the middle of the whorl curve in an opisthocline direction and meet the upper suture at an angle of about 80 degrees (Fig. 1G); the costae disappear slightly below the lower suture.

Discussion. - The teleoconch morphology of Palaeozygopleura vaneki sp. nov. is close to that in Palaeozygopleura (Palaeozygopleura) vesna Horný, 1955. The latter species is known only from three shells coming from uppermost layers of Třebotov Limestone (Emsian/Eifelian boundary beds), Holyně near Prague. Palaeozygopleura vaneki has a higher number of costae, which are also more asymmetrically curved, than Palaeozygopleura $(P$.) vesna. Costae in Palaeozygopleura vaneki have a triangular profile in contrast to the two-edged costae in Palaeozygopleura (P.) vesna (Horný 1955, tab. 3.3, p. 38). In the latter species the distance of costae separation is equal to their width, but this distance is about double in Palaeozygopleura vaneki (Fig. $1 \mathrm{H})$.

Occurrence. - Palaeozygopleura vaneki is a common species at the type locality and has also been found NE of Hostim (about $20 \mathrm{~km} \mathrm{SW}$ of Prague) in the Chýnice Limestone (coll. L. Ferrová).

\section{Notes on phylogeny of Loxonematoidea and origin of planktotrophy}

Many opinions have been given on the phylogeny of the superfamily Loxonematoidea (including Palaeozygopleuridae) and this superfamily has been placed in the Archaeogastropoda, Caenogastropoda, or Heterobranchia (Wenz 1938, Horný 1955, Knight et al. 1960, Golikov \& Starobogatov 1975, Ponder \& Warén 1988). Bandel (1991) sug- gested that the Loxonematoidea represents a polyphyletic group and placed the families Pseudozygopleuridae and Zygopleuridae together with his new family Protorculidae into the newly established superfamily Zygopleuroidea of the Ctenoglossa. On the other hand, the Loxonematidae together with his new family Polygyrinidae were placed into the Mesogastropoda. Frýda \& Bandel (1997) pointed out that Early Devonian members of the Loxonematidae and Palaeozygopleuridae have large protoconchs formed by less than one whorl. They interpreted these large protoconchs as being formed only by the embryonic shells and mentioned the similarity of early shell ontogeny (absence of the larval shell) in loxonematoidean gastropods to that found in members of the Archaeogastropoda and Patellogastropoda. Nützel (1998) analyzed in detail the classification and evolutionary history of the Ptenoglossa and interpreted the superfamily Zygopleuroidea as a parataxon. He also suggested that large non-planktotrophic protoconchs of the Devonian Palaeozygopleuridae could reflect their living in a deeper-water environment. However, Frýda (1999b) later noted that these gastropods lived in other habitats including relatively shallow-water environments.

Discussion on the phylogenetic relationships of loxonematoidean gastropods has focused on the nature of the protoconch. There are two different interpretations of this feature - (1) the protoconch represents the embryonic and larval shell (Horný 1955), simplified by lecitotrophic development (Nützel 1998); and, (2) the palaeozygopleurid protoconch is formed only by the embryonic shell (Frýda \& Bandel 1997). The first interpretation means that they might belong to the Caenogastropoda whereas the second interpretation suggests their affinity with groups like the Archaeogastropoda, Euomphalomorpha, and Patellogastropoda. The very close similarity of the teleoconch characters of Devonian palaeozygopleurid and Late Paleozoic pseudozygopleurid gastropods seems to strongly support the placement of both groups in the Caenogastropoda because the pseudozygopleurid protoconch is without doubt of caenogastropod type (Knight 1930; Bandel 1991, 2002a; Nützel 1998). Taken together, the basic question is whether or not palaeozygopleurid gastropods developed a larval shell (protoconch II) like many groups of "advanced" gastropods. The development of larval shells is considered to be linked with the origin of planktotrophy.

The origin of planktotrophy within the Class Gastropoda has been a frequently discussed problem and one of most important and still unsolved questions is whether planktotrophy originated once or several times (see Haszprunar 1995, Frýda et al. 2008). Some paleontological data suggest that planktotrophy was present even in the Ordovician (see discussion in Chaffee \& Lindberg 1986; Frýda \& Rohr 2004; Nützel et al. 2006, 2007; Freeman \& Lundelius 2007; Runnegar 2007). There 
exist several groups among Ordovician and Silurian gastropods that developed larval shells (i.e. protoconch II), such as the Cyrtoneritimorpha, Perunelomorpha, and Mimospirina; see detailed discussion in Frýda 1999a, Frýda \& Rohr 2004, and Frýda et al. 2008. Among extant gastropods development of protoconch II (larval shell) is present only in the Neritimorpha, Caenogastropoda and Heterobranchia, which can have a planktotrophic or a lecitotrophic strategy. Planktotrophic taxa that use external food sources during their larval stage typically have small embryonic shells. Lecitotrophic taxa have large embryonic shells and their larval shells are typically reduced in the number of whorls. These facts strongly suggest that the development of the larval shell is closely connected with a strategy to extend early ontogeny and to use the external food source before metamorphosis. Thus, small embryonic shells and the development of larval shells in some Early Paleozoic gastropods does not mean that those gastropods had a planktotrophic strategy but may only suggest that they used an external food source before metamorphosis. The oldest gastropods having a larval shell of the same morphology as living marine gastropods are known from the Devonian but become more frequent since the Carboniferous (Frýda 2001; Nützel 1998; Nützel \& Bandel 2000; Nützel \& Mapes 2001; Nützel \& Pan Hua-Zhang 2005; Bandel 2002a, b, 2007; Frýda et al. 2008 and references herein). Frýda (1998, 1999a) found open-coiled protoconchs in several unrelated gastropod lineages and pointed out that this morphological state might represent a plesiomorphic feature. He also noted that open-coiled protoconchs were apparently lost in multiple, unrelated gastropod lineages. Later Nützel \& Frýda (2003) quantitatively documented this macroevolutionary trend showing decreasing proportions of open-coiled protoconchs throughout the Paleozoic. They also hypothesized that this distinct change in protoconch morphology (i.e. from open-coiled to closely coiled) was probably the result of increasing predatory activity. Predation on Devonian plankton was recently documented by Berkyová et al. (2007). An accompanying trend toward smaller embryonic shells was observed in Silurian and Devonian gastropods (Frýda 2004). This morphological change coincided with the inception of larval planktotrophy and was followed by the Late Paleozoic radiation of Neritimorpha, Caenogastropoda, and Heterobranchia. Frýda (2004) suggested that fundamental changes in biogeochemical evolution of the Paleozoic oceans, linked to a pronounced increase in nutrient input to surface sea waters during eutrophication episodes, triggered both the inception of larval planktotrophy and the diversification of groups with such larva.

In this context, we can re-evaluate observed data on palaeozygopleurid gastropods. The most important facts are as follows: (1) there is a transition in "typical" teleoconch features between members of the Loxonematidae and Palaeozygopleuridae (Frýda 1993); (2) all known protoconchs in the Loxonematidae and Palaeozygopleuridae have the same morphology and are formed by a large shell having less than one whorl (Horný 1955, Frýda \& Bandel 1997, Frýda 1999a); (3) there is a strong similarity in teleoconch features (including characteristic ornamentation) among the palaeozygopleurid and pseudozygopleurid gastropods; and, (4) pseudozygopleurid gastropods belong without doubt to the Caenogastropoda, probably to the Ptenoglossa lineage (Bandel 1991, Nützel 1998).

As mentioned above, two different interpretations of these facts have been published - (1) the palaeozygopleurid protoconch is formed by embryonic and larval shells being reduced because of lecitotrophy strategy, and (2) the palaeozygopleurid protoconch consists of only a large embryonic shell. The first interpretation suggests that the Palaeozygopleuridae may represent an ancestral or sister group of the Pseudozygopleuridae (Horný 1955), whereas the second interpretation results in an opinion that both groups are not closely related. However, there is also another possible interpretation. Palaeozygopleurid gastropods developing only a large embryonic shell might represent a grade before adaptation to a new planktonic food source. During the Devonian some palaeozygopleurids might have adapted to this food source, extending their larval stage and starting to build a larval shell (protoconch II). If so, then the palaeozygopleurid protoconch is not a secondarily reduced larval shell, but rather a large embryonic shell. Nevertheless, palaeozygopleurid and pseudozygopleurid gastropods may be closely related groups as suggested by Horný (1955) on the basis of their teleoconch similarities. Even though a multiple origin of planktotrophy in different gastropod lineages seems to be less probable and parsimonious than a single origin, it is not in conflict with the fossil record (see Frýda 1999a, Frýda \& Rohr 2004, Frýda et al. 2008). This process might have been linked to the Paleozoic plankton revolution (Nützel \& Frýda 2003). The evolutionary advantage of a planktotrophic strategy over simple lecitotrophy (as seen for example in vetigastropods) may be illustrated by the increasing portion of gastropod groups developing larval shells during the last $400 \mathrm{My}$. Such gastropods form the vast majority of living species in modern marine faunas.

\section{Acknowledgements}

The work was supported by grants from the Czech Academy of Science (KJB307020602), the Grant Agency of the Czech Republic (205/08/0062), and the Czech-American Cooperation Programme (Kontakt ME08011). The authors thank Robert B. Blodgett (Anchorage) and Štěpán Manda (Prague) for their helpful reviews. 


\section{References}

AMLER, M.R.W. \& HeIDELBERGER, D. 2003. Late Famennian Gastropoda from south-west England. Palaeontology 46(6), 1151-1211. DOI 10.1046/j.0031-0239.2003.00338.x

BANDEL, K. 1991. Über triassische "Loxonematoidea" und ihre Beziehungen zu rezenten und palaeozoischen Schnecken. Palaeontologische Zeitschrift 65(3-4), 239-268.

BANDEL, K. 2002a. Reevaluation and classification of Carboniferous and Permian Gastropoda belonging to the Caenogastropoda and their relation. Mitteilungen aus dem Geologisch-Paläontologischen Institut der Universität Hamburg 86, 81-188.

BANDEL, K. 2002b. About the Heterostropha (Gastropoda) from the Carboniferous and Permian. Mitteilungen aus dem Geologisch-Paläontologischen Institut der Universität Hamburg 86, 45-80.

BANDEL, K. 2007. Description and classification of Late Triassic Neritimorpha (Gastropoda, Mollusca) from St. Cassian Formation, Italian Alps. Bulletin of Geosciences 82(3), 215-274. DOI 10.3140/bull.geosci.2007.03.215

BERKYOVÁ, S., FRÝDA, J. \& LUKEŠ, P. 2007. The first documentation of unsuccessful predation on the Middle Paleozoic plankton. Acta Palaeontologica Polonica 52(2), 407-412.

BLODGETT, R.B. 1992. Taxonomy and paleobiogeographic affinities of an early Middle Devonian (Eifelian) Gastropod faunule from the Livengood Quadrangle, East-Central Alaska. Palaeontographica, Abteilung A 221, 125-168.

BlodgetT, R.B. \& Johnson, J.G. 1992. Early Middle Devonian (Eifelian) gastropods of central Nevada. Palaeontographica, Abteilung A 222, 83-139.

BlodgetT, R.B., RoHR, D.M. \& Boucot, A.J. 1988. Lower Devonian gastropod biogeography of the Western Hemisphere. In MCMillan, N.J., EMBRY, A.F. \& GLASS, D.J. (eds) Devonian of the World. Canadian Society of Petroleum Geologists Memoir 14(3), 281-294.

BLODGETT, R.B., ROHR, D.M. \& BouCOT, A.J. 1990. Early and Middle Devonian gastropod paleobiogeography, 277-284. In MCKerRow, W.S. \& SCOTESE, C.R. (eds) Palaeozoic Palaeogeography and Biogeography. Geological Society (London) Memoir 12.

BlodgetT, R.B., FRÝDA, J. \& RACHEBOEUf, P.R. 1999. Upper Middle Devonian (Givetian) gastropods from the Kersiadou Formation, Brittany, France. Journal of Paleontology 73(6), 1081-1100.

Bouchet, P., Rocroi, J.P., FrÝdA, J., HAUSDORF, B., PONDER, W., VALDES, A. \& WARÉN, A. 2005. Classification and nomenclator of gastropod families. Malacologia 47(1-2), 1-368.

CARls, P., SlavíK, L. \& VAlenZuela-Ríos, J.I. 2007. Revisions of conodont biostratigraphy across the Silurian-Devonian boundary. Bulletin of Geosciences 82(2), 145-164. DOI 10.3140/bull.geosci.2007.02.145

ChAFFEE, C. \& LindBerG, D.L. 1986. Larval biology of Early Cambrian molluscs: the implication of small body size. Bulletin Marine Science 39, 536-549.

CHLUPÁČ, I. 1959. Faciální vývoj a biostratigrafie břidlic dalejských a vápenců hlubočepských (eifel) ve středočeském devonu. Sborník Ústředního ústavu geologického, Oddíl geologický 24, 446-511.

ChluPÁČ, I. 1984. Devon. In KovandA, J., BRUNNEROVÁ, Z., CHLuPÁČ, I., HAVlíčEK, V., KleIN, V., KŘíž, J., LOCHMANN, Z., ŠALANSKÝ, K., ŠEFRNA, L., ŠTYCH, J., TOMÁŠEK, M. \& ZELENKA, P. Vysvětlivky k základní geologické mapě C̆SSR 1 : 25 000, 12-412 Rudná. Ústřední ústav geologický, Praha.

CoOK, A.G. 1995. Gastropods from the Ukalunda Beds and Douglas Creek, Early Devonian, north Queensland. Memoirs of the Queensland Museum 38(2), 429-435.

CoOK, A.G. 1997. Gastropods from the Burdekin Formation, Middle Devonian, north Queensland. Memoirs of the Queensland Museum 42(1), 37-49.

COOK, A.G., BLODGETT, R.B. \& BECKER, R.T. 2003. Late Devonian gastropods from the Canning Basin, Western Australia. Alcheringa 27(3-4), 181-207.

CoOK, A.G. \& CAMILLERI, N. 1997. Middle Devonian gastropods from the Broken River Province, north Queensland. Memoirs of the Queensland Museum 42(1), 55-79.

COOK, A.G. \& NÜTZEL, A. 2005. New Devonian gastropods from the Broken River and their palaeoecology. Memoirs of the Queensland Museum 51, 391-397.

CUVIER, G. 1797. Tableau élémentaire de l'histoire naturelle des animaux. 710 pp. Paris.

FREEMAN, G. \& Lundelius, J.W. 2007. Origin of planktotrophy - evidence from early molluscs: a response to Nützel et al. (2006). Evolution \& Development 9(4), 307-310. DOI 10.1111/j.1525-142X.2007.00164.X

FRÝDA, J. 1993. Oldest representative of the family Palaeozygpleuridae (Gastropoda) with notes on its higher taxonomy. Journal of Paleontology 67, 822-828.

FRÝDA, J. 1998. Did the ancestors of higher gastropods (Neritimorpha, Caenogastropoda, and Heterostropha) have an uncoiled shell? In BIELER, R. \& MIKKELSEN, P.M. (eds) Abstracts, World Congress of Malacology. UNITAS Malacologica, Chicago.

FRÝDA, J. 1999a. Higher classification of Paleozoic gastropods inferred from their early shell ontogeny. Journal of the Czech Geological Society 44, 137-152.

FRÝDA, J. 1999b. Further new gastropods from the Early Devonian Boucotonotus-Palaeozygopleura Community of the Prague Basin. Journal of the Czech Geological Society 44, 317-325.

FRÝDA, J. 2000. Some new Givetian (Late Middle Devonian) gastropods from the Paffrath area (Bergisches Land, Germany). Memoirs of the Queensland Museum 45(2), 359-374.

FRÝDA, J. 2001. Discovery of a larval shell in Middle Paleozoic subulitoidean gastropods with description of two new species from the Early Devonian of Bohemia. Bulletin of the Czech Geological Survey 76, 29-37.

FRÝDA, J. 2004. Phylogeny of Paleozoic gastropods and origin of larval planktotrophy. In WeLLS, F.E. (ed.) Abstracts, World Congress of Malacology Perth, UNITAS Malacologica.

FRÝDA, J. \& BANDEL, K. 1997. New Early Devonian gastropods from the Plectonotus (Boucotonotus)-Palaeozygopleura community in the Prague Basin (Bohemia). Mitteilungen aus dem 
Geologisch-Paläontologischen Institut der Universität Hamburg 80, 1-57.

FRÝDA, J. \& BLODGETT, R.B. 2004. New Emsian (Late Early Devonian) gastropods from Limestone Mountain, Medfra B-4 Quadrangle, west-central Alaska (Farewell Terrane), and their paleobiogeographic affinities and evolutionary significance. Journal of Paleontology 78(1), 111-132.

DOI 10.1666/0022-3360(2004)078<0111:NELEDG > 2.0.CO;2

FRÝDA, J. \& MANDA, Š. 1997. A gastropod faunule from the Monograptus uniformis graptolite Biozone (Early Lochkovian, Early Devonian) in Bohemia. Mitteilungen aus dem Geologisch-Paläontologischen Institut der Universität Hamburg 80, 59-122.

FRÝDA, J., NÜTZEL, A. \& WAGNER, P.J. 2008. Paleozoic gastropods, 237-268. In PONDER, W. \& LINDBERG, D.L. (eds) Phylogeny and Evolution of the Mollusca. 466 pp. University of California Press, Berkeley and Los Angeles, California.

FRÝDA, J. \& ROHR, D.M. 2004. Gastropods, 184-195. In WEBBY, B.D., PARIS, F., Droser, M.L. \& Percival, I.G. (eds) The Great Ordovician Biodiversification Event. Columbia University Press, New York.

Golikov, A.N. \& Starobogatov, Y.I. 1975. Systematics of prosobranch gastropods. Malacologia 15(1), 185-232.

Gubanov, A.P., BlodgetT, R.B., \& LytochKin, V.N. 1995. Early Devonian (Pragian) gastropods from Kyrgyzstan (Central Asia). Journal of Paleontology 69, 431-440.

HASZPRUNAR, G. 1995. On the evolution of larval development in the Gastropoda, with special reference to larval planktotrophy. Notiz CISMA 16, 5-13.

HAVLÍČEK, V. \& VANĚK, J. 1996. Brachiopods and trilobites in the Chýnice Limestone (Emsian) at Bubovice (Čeřinka hillside; Prague Basin). Palaeontologia Bohemiae II(1), $1-16$.

HEIDELBERGER, D. 2001. Mitteldevonische (Givetische) Gastropoden (Mollusca) aus der Lahnmulde (suedliches Rheinisches Schiefergebirge). Geologische Abhandlungen Hessen 106, $1-291$.

HEIDELBERGER, D. 2007. Neue Erkenntnisse zu mikromorphen Gastropoden aus Sötenich (Givetium, Mittle-Devon). Palaeontologische Zeitschrift 81(3), 229-237.

HeIDElberger, D. \& BANDEL, K. 1999. Micromorph Gastropoda from the Middle Devonian (Givetian) limestone of the Sötenich Syncline (Eifel). Mitteilungen aus dem Geologisch-Paläontologischen Institut der Universität Hamburg 83, 129-162.

HeIDELBERGER, D. \& KoCH, L. 2005. Gastropoda from the Givetian "Massenkalk" of Schwelm and Hohenlimburg (Saureland, Rheinsiches Schiefergebirge, Germany). Geologica et Palaeontologica 4, 1-107.

HORNÝ, R.J. 1955. Palaeozygopleuridae nov. fam. (Gastropoda) ze středočeského devonu. Sborník Ústředního ústavu geologického, Oddíl paleontologický 21(1), 17-74.

Kesling, R. V. \& Chilman, R.B. 1975. Strata and megafossils of the Middle Devonian Silica Formation. University of Michigan Papers on Paleontology 8, 1-408.

KNIGHT, J.B. 1930. The gastropods of the St. Louis, Missouri,
Pennsylvanian outlier: the Pseudozygopleurinae. Journal of Paleontology Memoir 4(4), 1-88.

KNight, J.B., CoX, L.R., BATten, R.L. \& Yochelson, E.L. 1960. Systematic descriptions. In MOORE, R.C. (ed.) Treatise on invertebrate paleontology. Part I. Mollusca 1. University of Kansas Press, Lawrence, Kansas.

KOKEN, E. 1889. Ueber die Entwicklung der gastropoden vom Cambrium bis zur Trias. Neues Jahrbuch für Mineralogie, Geologie und Paläontologie, Beilage Band 6, 305-484.

KRAWCZYŃSKI, W. 2002. Frasnian gastropod synecology and bio-events in the Dyminy reef complex of the Holy Cross Mountains, Poland. Acta Palaeontologica Polonica 47(2), 267-288.

KRAWCZYŃSKI, W. 2006. Gastropod succession across the Early-Middle Frasnian transition in the Holy Cross Mountains, southern Poland. Acta Palaeontologica Polonica 51(4), 679-693.

LINSLEY, R.M. 1968. Gastropods of the Middle Devonian Anderdon Limestone. Bulletins of American Paleontology 54, 333-465.

NÜTZEL, A. 1998. Über die Stammesgeschichte der Ptenoglossa (Gastropoda). Berliner Geowissenschaftliche Abhandlungen, Reihe E, Paläobiologie 26(1), 1-225.

NÜTZEL, A. \& BANDEL, K. 2000. Goniasmidae and Orthonemidae: two new families of Palaeozoic Caenogastropoda. Neues Jahrbuch für Geologie und Paläontologie, Monatshefte 9, 557-569.

NÜTZEL, A. \& FRÝDA, J. 2003. Paleozoic plankton revolution: evidence from early gastropod ontogeny. Geology 31, 829-831. DOI 10.1130/G19616.1

NÜTZEL, A., LEHNERT, O. \& FRÝDA, J. 2006. Origin of planktotrophy - evidence from early molluscs. Evolution \& Development 8(4), 325-330.DOI 10.1111/j.1525-142X.2006.00105.x

NÜTZEL, A., LEHNERT, O. \& FRÝDA, J. 2007. Origin of planktotrophy - evidence from early molluscs: a response to Freeman and Lundelius. Evolution \& Development 9(4), 312-317. DOI 10.1111/j.1525-142X.2007.00166.X

NÜTZEL, A. \& MAPES, R. H. 2001. Larval and juvenile gastropods from a Mississippian black shale: Paleoecology, and implications for the evolution of the Gastropoda. Lethaia 34, 143-162.

NÜTZEL, A. \& PAN HUA-ZHANG 2005. Late Paleozoic evolution of the Caenogastropoda: larval shell morphology and implications for the Permian/Triassic mass extinction event. Journal of Paleontology 79, 1175-1188.

PERNER, J. 1903, 1907, 1911. Gastéropodes, 1-390. In BARRANDE, J. Systême Silurien du centre de la Bohême IV. Prague.

PONDER, W.F. \& WARÉN, A. 1988. Classification of the Caenogastropoda and Heterostropha - a list of the familygroup names and higher taxa, 288-326. In PONDER, W.F. (ed.) Prosobranch Phylogeny, Malacological Review Supplement.

RoHr, D.M., BlodgetT, R.B. \& FrÝDA, J. 2008. Silurian Gastropoda from Prince of Wales Island, southeastern Alaska. Journal of Paleontology 82(3), 604-611.

Rollins, H.B., ELDREDGE, N. \& SPILLER, J. 1971. Gastropoda 
and Monoplacophora of the Solsville Member (Middle Devonian, Marcellus Formation) in the Chenango Valley, New York State. Bulletin of the American Museum of Natural History 144, 129-170.

RunNEGAR, B. 2007. No evidence for planktotrophy in Cambrian molluscs. Evolution \& Development 9(4), 311-312. DOI 10.1111/j.1525-142X.2007.00165.x

TASSELL, C.B. 1982. Gastropods from the Early Devonian "Receptaculites" Limestone, Taemas, New South Wales. Records of the Queen Victoria Museum 77, 1-59.
TUREK, V. 2007. Systematic position and variability of the Devonian nautiloids Hercoceras and Ptenoceras from the Prague Basin (Czech Republic). Bulletin of Geosciences 82(1), 1-10. DOI 10.3140/bull.geosci.2007.01.1

WENZ, W. 1938-1944. Gastropoda, 1-1639. In SCHINDEWOLF, O.H. (ed.) Vol. Band 6, Teil 1-7, Handbuch der Paläozoologie. Bonntraeger, Berlin.

ZuSKOVÁ, J. 1991. Conodont faunas from the Lower/Middle Devonian section in Praha - Barrandov. Věstník ústředního ústavu geologického, 66 (2), 107-112. 